\title{
Frequent blood sampling changes the plasma concentration of LH and FSH and the ovulation rate in Merino ewes
}

\author{
N. R. Adams ${ }^{1}$, S. Atkinson ${ }^{1 *}$, G. B. Martin ${ }^{1,2}$, J. R. Briegel ${ }^{1}$, \\ R. Boukhliq ${ }^{2}$ and M. R. Sanders ${ }^{1}$ \\ ${ }^{1}$ Division of Animal Production, CSIRO, PO Wembley, WA 6014, Australia; and ${ }^{2}$ Animal Science \\ Group, The University of Western Australia, Nedlands WA 6009, Australia
}

\begin{abstract}
During earlier studies we observed that ewes housed and sampled intensively to measure pulses of LH in plasma had a higher ovulation rate than similar ewes housed outside. In Expt 1, we pursued this observation by testing whether the increase was due to effects of housing or collection of blood samples. Ewes sampled at intervals of $4 \mathrm{~h}$ for 2 days before progestagen sponge removal and 2 days after sponge removal, and every $20 \mathrm{~min}$ for $12 \mathrm{~h}$ the day before sponge removal and every $10 \mathrm{~min}$ for $4 \mathrm{~h}$ on the day of sponge removal had a higher ovulation rate than ewes that were not sampled (1.72 versus $1.41 ; P<0.05$ ). The ovulation rate of the ewes housed indoors but not sampled was similar to that of ewes that remained in the paddock (1.43). In Expt 2, we studied the effects of blood sampling in three groups of 20 ewes sampled every 20 min for different periods of $24 \mathrm{~h}$. Ewes from all three groups were sampled the day before sponge removal (day -1 ) and, in addition, one group of ewes was sampled for the previous $48 \mathrm{~h}$ (i.e. days -3 to -1 ) and another group was sampled on day -8 . The frequency of LH pulses was lower $(P<0.05)$ in ewes sampled for the first time on day -1 compared with the frequency of LH pulses in groups also sampled earlier in the cycle (day -8 or days -3 and -2 ). In ewes sampled on days -3 to -1 , the frequency of LH pulses was low for the first $24 \mathrm{~h}$ and then increased. Changes in the mean concentration of FSH followed a pattern similar to that of LH pulse frequency. The ovulation rate was increased in ewes sampled on day $-8(P<0.01)$ compared with a control group of 40 unsampled ewes. We conclude that collection of blood samples from Merino ewes to measure LH pulses can change the frequency of those pulses and the mean concentration of FSH, and these changes can be accompanied by an altered ovulation rate.
\end{abstract}

\section{Introduction}

In females of most species, stress can act by both peripheral and central mechanisms to affect the secretion of gonadotrophins and ovarian function (for review see Rivier and Rivest, 1991). In female sheep, stresses associated with housing or confinement reduce the frequency of LH pulses (Rasmussen and Malven, 1983; Rawlings and Cook, 1991) and more severe stresses, such as high ambient temperatures, repeated laparoscopy or footshocks, alter the hypothalamic distribution of $\mathrm{GnRH}$ and delay or block the LH surge and ovulation (Sawyer et al., 1979; Martin et al., 1981; Przekop et al., 1984, 1988). Paradoxically, transport ('trucking stress') has been shown to induce ovulation in anoestrus ewes (Braden and Moule, 1964) through an, as yet, unknown mechanism.

The endocrine system of sheep appears to acclimatize to stress relatively rapidly (Rasmussen and Malven, 1983; Rawlings and Cook, 1991), so that workers tend to ignore these effects or

${ }^{*}$ Current address: HIMB, 1000 Pope Rd, MSB 212, University of Hawaii, Honolulu, Hawaii 96822, USA.

Revised manuscript received 4 May 1993. presume they are compensated for in the experimental design. The general contention that the reproductive system of ewes is relatively resistant to stress is supported by the lack of effects of glucocorticoids on the hypothalamic-ovarian axis. Cortisol or dexamethasone do not affect the timing or magnitude of the $\mathrm{LH}$ surge, the tonic secretion of $\mathrm{LH}$ and FSH, or the ovulation rate (Moberg et al., 1981; Phillips et al., 1987; Phillips and Clarke, 1990). By contrast, similar doses of glucocorticoids block oestrus and ovulation in cattle and swine (Li and Wagner, 1983; Pearce et al., 1988).

During studies examining the control of ovulation rate in Merino ewes, we noted that ewes held indoors and sampled every 20 min to study their LH pulses had a higher ovulation rate than control ewes held outdoors and sampled only daily (Adams and Atkinson, unpublished). This analysis was retrospective and housing and bleeding regimen were confounded in the design of the study; we therefore carried out the experiments reported here to confirm the observation on ovulation rate, to test for a critical period in the cycle when sampling affects ovulation, and to test whether the ewe can be acclimatized to intensive collection of blood samples. 


\section{Materials and Methods}

\section{Experiment 1}

In this study, 160 mature Merino ewes were used to compare effects of housing and collection of blood samples on ovulation rate. The ewes were allocated to four groups that were grazed on pasture $(n=80)$, housed but not sampled $(n=40)$, housed and sampled infrequently $(n=20)$, or housed and sampled frequently $(n=20)$.

The oestrous cycles of the ewes were synchronized with intravaginal sponges containing $60 \mathrm{mg}$ medroxyprogesterone acetate (Repromap: Upjohn, MI) 6 days before the study commenced. The study was carried out in autumn, in fine weather with a mean maximum temperature of $28^{\circ} \mathrm{C}$. An outline of the treatment groups and sampling times is given (Fig. 1a). The flock was stratified on liveweight, and half remained in the paddock eating dried pasture, while the other 80 were brought indoors to a shed open on one side and fed ad libitum on a ration of hammer-milled oaten hay plus $10 \%$ lupin grain. After 3 days, the 80 ewes indoors were allocated to two groups: 40 ewes were not treated further, and the remaining 40 ewes were fitted with jugular catheters and $3 \mathrm{ml}$ blood samples collected every $4 \mathrm{~h}$ for 4 days to measure $\mathrm{FSH}$. The ewes were run together as a group and were briefly placed in a race to collect the samples. After the sample was withdrawn, the catheter was filled with $2.5 \mathrm{ml}$ heparinized saline ( $5 \mathrm{iu}$ heparin $\mathrm{ml}^{-1}$ ) and the ewes returned to the pen. All operations were carried out as quietly as possible, and no dogs were permitted in the vicinity. Intravaginal sponges were removed from all ewes 2 days after sampling commenced. Additional $3 \mathrm{ml}$ samples were collected from half of the catheterized ewes every $20 \mathrm{~min}$ for $12 \mathrm{~h}$ on the day before sponge removal, and every $10 \mathrm{~min}$ for $4 \mathrm{~h}$ starting $16 \mathrm{~h}$ after sponge removal (Fig. 1a). These samples were collected by placing ewes together in a small pen that restricted movement throughout the $4 \mathrm{~h}$ sampling period. Laparoscopy was performed under local anaesthesia 7 days after sponge removal, and the number of corpora lutea on the ovaries was recorded for all 160 ewes.

\section{Experiment 2}

This study examined effects of sampling on gonadotrophin secretion and ovulation rate in 100 mature Merino ewes (mean weight $56 \mathrm{~kg}$ ) that were assigned to four groups, one of which $(n=40)$ was not sampled, and three groups of 20 ewes that were sampled at $20 \mathrm{~min}$ intervals for $24 \mathrm{~h}$ periods on various days. The sampling regimen (outlined in Fig. Ib) was designed to test the effect of sampling 8 days previously, or for the previous $48 \mathrm{~h}$, on gonadotrophin concentrations in plasma the day before removal of progestogen sponges.

The ewes, which had lambed 9 months previously, were brought into the animal house, fed ad libitum on a diet of oaten chaff with $10 \%$ lupin grain, and kept in groups of six or seven in $9 \mathrm{~m} \times 9 \mathrm{~m}$ pens. On day $-14,11$ days after introduction into the pens, all the ewes were given s.c. progesterone implants (Silestrus; Abbott Labs, Eastwood NSW) and assigned to treatment groups (Fig. Ib). The 40 control ewes were not sampled, and the other three groups of 20 were sampled on days -3 , -2 and -1 (group 1), on day -1 alone (group 2), or on day (a)

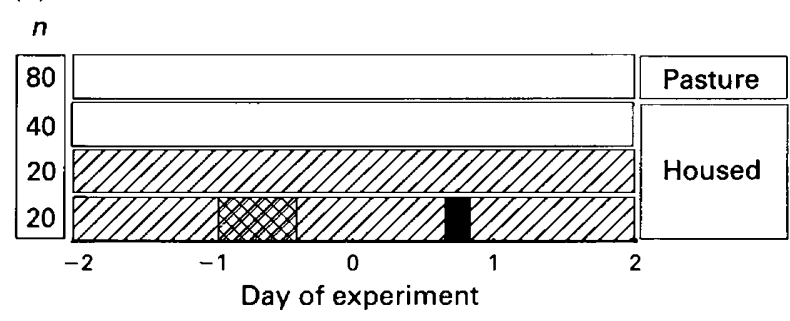

(b)

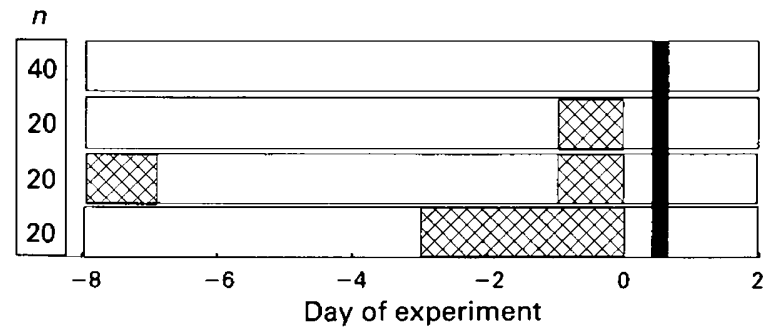

Fig. 1. Treatment and sampling protocols for (a) Expt 1 and (b) Expt 2. Groups of ewes were sampled each $4 \mathrm{~h}(\nabla), 20 \mathrm{~min}(\mathrm{Q})$ or $10 \mathrm{~min}(\mathbf{\square})$ at the times indicated. Progestagen sponges were removed at day 0 . In Expt 1, ewes were run at pasture or housed, as indicated. In Expt 2, all ewes were housed.

-8 and -1 (group 3). The day before sampling, a jugular catheter was inserted in ewes after tranquillization with $15 \mathrm{mg}$ acetyl promazine i.m. (Promex 10: Apex Labs, St Marys, NSW). On each day of blood sampling, $3 \mathrm{ml}$ blood was collected every $20 \mathrm{~min}$ for $24 \mathrm{~h}$, and every effort was made to ensure minimal disturbance or stress to the sheep. Ewes remained loose in their group pens and were sufficiently tame to stand still when approached for sampling. On day 0 , the progesterone implants were removed and $16 \mathrm{~h}$ later blood samples were collected at intervals of $10 \mathrm{~min}$ for $4 \mathrm{~h}$ from eight ewes from each group of 20 ewes. The ovaries of all the ewes were examined by laparoscopy 8 days after progesterone withdrawal (day 8 ), and the number of corpora lutea determined.

\section{Hormone assays}

Follicle-stimulating hormone. Plasma concentrations of FSH were assayed using radioimmunoassay reagents kindly supplied by A. F. Parlow of the National Institute of Diabetes, Digestive and Kidney Diseases (Baltimore, MD), as described by Atkinson and Adams (1988). The assay used antiserum oFSH-1, reference preparation oFSH-RP-1 (biopotency 75 iu NIH-FSH-S1 mg ${ }^{-1}$ ) and tracer preparation oFSH-I-1. The limit of detection of the assay was $0.12 \pm 0.01 \mathrm{ng} \mathrm{ml}^{-1}$. All samples were measured within a single assay. Samples with mean concentrations of $1.24,3.22$ and $7.34 \mathrm{ng} \mathrm{ml}^{-1}$ had intra-assay coefficients of variation of $11.5,10.2$ and $10.9 \%$, respectively.

Ovine luteinizing hormone. Plasma concentrations of LH were measured using an assay similar to that reported by Martin et al. (1980), except that anti-LH serum UWA-Jack, which shares negligible crossreaction with all pituitary hormones 
except NIAMDD-oFSH-RP-1 (14\%) was used. The preparation CNRS-M3 (biopotency 1.8 iu NIH-LH-SI $\mathrm{mg}^{-1}$ ) used for both iodination and reference was kindly supplied by $\mathrm{M}$. Jutisz (College de France). The samples were assayed as duplicate $100 \mu \mathrm{l}$ aliquots. The limit of detection was $0.04 \mathrm{ng}$ per tube. Assay variation was estimated using pooled plasma samples containing 1.32 and $6.60 \mathrm{ng} \mathrm{ml}^{-1}$, which were assayed in at least eight replicates in each assay. The intra-assay coefficients of variation were 1.4 and $5.1 \%$, respectively, and the interassay coefficients of variation were $14.3 \%$ and $9.9 \%$, respectively. Animals from all treatment groups were included in each assay, and all samples from each animal were assayed in the same assay to minimize the effects of interassay variation on the detection of $\mathrm{LH}$ pulses.

Statistical analysis. Pulses of $\mathrm{LH}$ in the serial samples were analysed with a modified version of the 'Pulsar' algorithm developed by Merriam and Wachter (1982) and modified for the Apple Macintosh computer ('Munro', Zaristow Software, West Morham, Haddington, East Lothian), as described by Martin et al. (1987). The $G$ parameters (the number of standard deviations by which a peak must exceed the baseline to be accepted) were 3.0, 2.8, 1.2, 0.9 and 0.6, these being the requirements for pulses composed of one to five samples that exceed the baseline, respectively. The Baxter parameters describing the parabolic relationship between the concentration of a hormone in a sample and the standard deviation (assay variation) about that concentration were 0.01344 (the $y$ intercept), 0.0483 (the $x$ coefficient) and -0.0001 ( $\times 2$ coefficient). The pulse frequency, mean pulse amplitudes (the difference between pulse peak and preceding nadir) and the mean concentration of LH was calculated for each profile.

Values for FSH were transformed logarithmically to homogenize the variances, and analysed by repeated measures analysis of variance. Ovulation rates, defined as the mean number of corpora lutea in ewes that ovulated, were compared by $\chi^{2}$ analysis. The effect of increasing frequency of sampling on ovulation rate in Expt $I$ was examined using the $Z$ test for linear trends in proportions (Snedecor and Cochran, 1967). In Expt 2, the significance of changes in gonadotrophin concentrations within individual sheep over successive periods of $24 \mathrm{~h}$ was determined by repeated measures analysis of variance.

\section{Results}

\section{Experiment 1}

Animals on pasture had an ovulation rate similar to animals housed but not sampled (Table 1). Among the ewes housed indoors, the ovulation rate increased linearly as the frequency of blood sampling increased (Table $1 ; Z=2.20, P<0.05$ ). In an individual comparison, the group of ewes sampled frequently to measure LH had a higher ovulation rate than that of ewes that were not sampled $\left(\chi^{2}=4.94, P<0.05\right)$.

The mean LH and FSH data from these animals was presented by Atkinson et al. (1989). The ewes sampled for LH had a mean of 0.7 pulses during the $12 \mathrm{~h}$ sampling period in the luteal phase, and 2.9 pulses during the $4 \mathrm{~h}$ sampling period in the follicular phase. The pattern of FSH secretion during the
Table 1. Effect of housing and frequency of blood sampling around the time of sponge withdrawal on ovulation rate in ewes

\begin{tabular}{|c|c|c|c|c|}
\hline \multirow[b]{2}{*}{ Treatment } & \multicolumn{3}{|c|}{$\begin{array}{c}\text { Number of corpora } \\
\text { lutea }\end{array}$} & \multirow{2}{*}{$\begin{array}{l}\text { Ovulation } \\
\text { rate }\end{array}$} \\
\hline & 0 & 1 & 2 & \\
\hline Outdoors & 7 & 41 & 31 & $1.43^{\mathrm{a}}$ \\
\hline Indoors, unsampled & 3 & 22 & 15 & $1.41^{\mathrm{a}}$ \\
\hline Indoors, sampled at $4 \mathrm{~h}$ intervals & 2 & 8 & 9 & $1.53^{\mathrm{ab}}$ \\
\hline $\begin{array}{l}\text { Indoors, sampled at } 4 \mathrm{~h} \text { intervals } \\
\text { and intensively }\end{array}$ & 2 & 5 & 13 & $1.72^{\mathrm{b}}$ \\
\hline
\end{tabular}

Values with different superscripts are significantly different, $P<0.05$; significant linear trend with increased blood sampling, $P<0.02$.

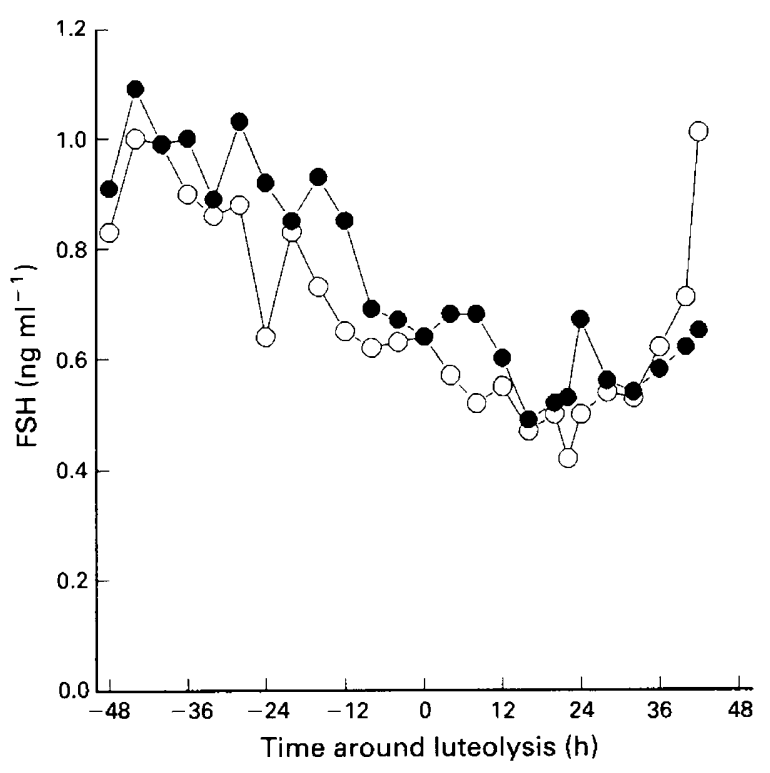

Fig. 2. Mean concentrations of FSH in plasma from ewes in Expt 1 , sampled at intervals of $4 \mathrm{~h}$ only $(\mathrm{O})$ and with additional $20 \mathrm{~min}$ sampling at -14 to $-2 \mathrm{~h}$ and $10 \mathrm{~min}$ sampling at $16-20 \mathrm{~h}(\mathrm{O})$. Vaginal progestagen sponges were removed at $0 \mathrm{~h}$.

experiment is shown (Fig. 2). In the group sampled at intervals of $4 \mathrm{~h}$ for FSH and the group sampled for FSH and intensively sampled for LH, FSH decreased significantly after the start of sampling $(P<0.01)$, and declined further after sponge withdrawal. There was no significant difference in plasma FSH values between the groups (Fig. 2). Similarly, comparison of the pooled values in the luteal or follicular phases revealed no difference between the two groups.

\section{Experiment 2}

The ovulation rate was higher $(P<0.001)$ in ewes from which blood was collected on day -8 , than in either group sampled later in the luteal phase (Table 2). Ewes sampled for 
Table 2. Effect of blood sampling on different days before sponge withdrawal on ovulation rate in ewes

\begin{tabular}{lrrrr}
\hline & \multicolumn{2}{c}{ Number of corpora lutea } & \\
\cline { 2 - 4 } Days sampled & 0 & 1 & 2 & $\begin{array}{c}\text { Ovulation } \\
\text { rate }\end{array}$ \\
\hline Not sampled & 5 & 20 & 12 & $1.38^{\mathrm{a}}$ \\
Day -1 & 1 & 13 & 4 & $1.24^{\mathrm{a}}$ \\
Days $-3,-2,-1$ & 1 & 8 & 11 & $1.58^{\mathrm{ab}}$ \\
Days $-8,-1$ & 2 & 1 & 17 & $1.94^{\mathrm{b}}$ \\
\hline
\end{tabular}

Values with different superscripts are significantly different $P<0.01$.
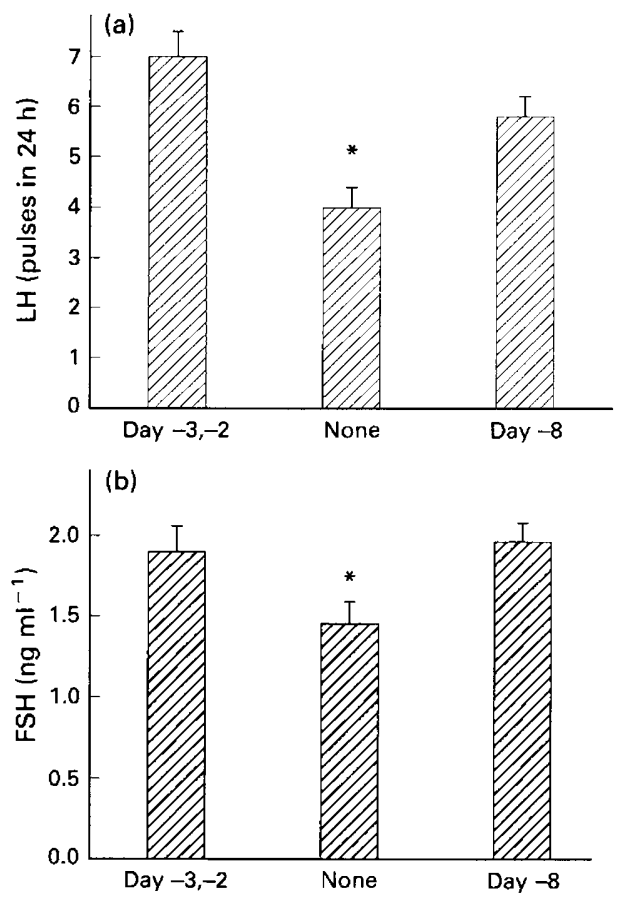

Fig. 3. (a) Mean ( \pm SEM) numbers of LH pulses on day $-\mathrm{I}$, the $24 \mathrm{~h}$ before progestagen sponge withdrawal and (b) mean concentration of FSH over the same period for ewes sampled for the preceding $48 \mathrm{~h}$ (day $-3,-2$ ), ewes not previously sampled, and ewes sampled 8 days previously (day -8 ) in Expt $2 .{ }^{*}$ Value differs significantly from other groups $(P<0.05)$.

$72 \mathrm{~h}$ before sponge withdrawal had a higher ovulation rate than those sampled only during the $24 \mathrm{~h}$ before sponge withdrawal $(P=0.06)$.

The frequency of LH pulses on the day before sponge withdrawal (day -1 ) was affected by previous sampling history. Ewes that had not been sampled previously had fewer LH pulses $(P<0.05)$ than did ewes sampled for the previous $48 \mathrm{~h}$, whereas in ewes sampled on day -8 and again on day -1 the number of LH pulses was intermediate between these two groups (Fig. 3a). Differences in the mean concentration of FSH followed a similar pattern. The mean concentration of FSH in plasma $24 \mathrm{~h}$ before sponge withdrawal was lower $(P<0.05)$ in ewes that had not been sampled previously than in those



Fig. 4. Mean ( \pm SEM) number of LH pulses (bars) and concentration of FSH $(O)$ in ewes sampled for $72 \mathrm{~h}$ before progestagen sponge withdrawal in Expt 2. ${ }^{*} \mathrm{LH}$ pulse frequency differs significantly from other groups $(P<0.01)$.

sampled during the previous $48 \mathrm{~h}$, or those sampled on day -8 (Fig. 3b).

Concentrations of gonadotrophins in the group sampled on days $-3,-2$ and -1 changed over the $72 \mathrm{~h}$. The frequency of LH pulses increased significantly $(P<0.01)$ in the second $24 \mathrm{~h}$ period, and then declined on day $3(P<0.01)$ (Fig. 4). In contrast, the concentration of FSH declined over the first $36 \mathrm{~h}$, and then increased (Fig. 4); the quadratic change with time was statistically significant $(P<0.01)$.

The ewes sampled on day -8 and day -1 had a similar mean concentration of FSH at both times $(1.82 \pm 0.17$ versus $1.96 \pm 0.12 \mathrm{ng} \mathrm{ml}^{-1}$ ), but the frequency of $\mathrm{LH}$ pulses was significantly lower at day -8 than on day $-1(2.25 \pm 0.34$ versus $5.30 \pm 0.66, P<0.001$ ).

There were no differences between the three groups in LH or FSH in the sheep sampled during the follicular phase. There were no statistically significant relationships between ovulation rate and gonadotrophin concentrations at any time.

\section{Discussion}

In this study, ovulation rate was increased by frequent collection of blood samples, but was not affected by simply housing ewes indoors. Blood sampling also affected the concentrations of gonadotrophins in the plasma. The differences in FSH and LH on day -1 in Expt 2 must be due to previous sampling history, as this was the only difference between the groups. There are no previous studies of these effects on ovulation rate, but housing (Rawlings and Cook, 1991) and close confinement (Rasmussen and Malven, 1983) were both reported to decrease the frequency of LH pulses in ewes for a short period until the ewes adapted to the new conditions.

It is difficult to attribute the increased ovulation rate and reduced gonadotrophin secretion observed in this work to what is commonly referred to as 'stress'. Stress is usually associated with a decrease in the twinning rate (Doney et al., 1976; Parr 
et al., 1989). Every effort was taken during these studies to minimize obvious stressors such as noise, sudden movement, confinement or restraint. The ewes appeared to adapt to the procedures within a few hours of the commencement of sampling and ruminated during sampling and appeared quieter and more at ease than the animals in the animal house that were not being sampled. Furthermore, Smith et al. (1992) observed an increased ovulation rate in sheep sampled by a remotely controlled sampling apparatus, and isolated from human contact, indicating that it is the sampling, rather than the associated stresses, that causes the increase.

Intensive sampling removed $220 \mathrm{ml}$ blood in a $24 \mathrm{~h}$ period, $5 \%$ of the estimated blood volume of the ewes. Even sampling for three consecutive days would not have been as stressful as a haemorrhage that removes $15 \%$ of the total blood volume within $10 \mathrm{~min}$, and such treatment has been shown to have no effect on GnRH secretion in rams (Caraty et al., 1988), so that loss of blood is unlikely to explain the effects reported here.

The relationship between the alterations in ovulation rate and gonadotrophin concentrations is not clear. The initial response to collection of blood samples was a decrease in the concentration of FSH (Expts 1 and 2) and the frequency of LH pulses (Expt 2). With continued sampling, LH pulse frequency rose in the second $24 \mathrm{~h}$ period, presumably to a more normal value, while FSH reached a nadir before increasing again. Such day-to-day changes in the latter part of the luteal phase have not been reported previously; it is therefore unlikely that these observations are confounded by the stage of the oestrous cycle. The initial decrease in gonadotrophic support for ovarian follicles probably resulted in follicular atresia and reduced negative feedback, allowing the secretion of gonadotrophins to increase ('rebound'), as has been observed in rams during continued sampling (Martin et al., 1989) and in ewes treated with exogenous inhibin (Wallace and McNeilly, 1985). However, we did not observe an increase in FSH concentration above initial values.

An understanding of the relationships between sampling, gonadotrophin secretion and ovulation rate is further complicated by differences in design between the two experiments. In Expt 1 , sampling continued throughout luteolysis; an increased ovulation rate may therefore have resulted from delayed onset of oestrus, as has been observed in ewes after administration of ACTH during this period (Doney et al., 1976). In Expt 2, sampling finished before luteolysis, except for a $4 \mathrm{~h}$ period, and the greatest effect on ovulation rate came from sampling earlier in the luteal phase. This effect may have resulted solely from changes in gonadotrophin concentrations, presumably occurring outside the sampling period.

The extent to which these observations on Merino ewes apply to other experimental models is unknown, but collection of blood samples increased ovulation rate in Romney $\times$ Dorset cross ewes (Smith et al., 1992) and unexplained increases in LH pulse frequency during an experiment were reported by Hall et al. (1992). Similarly, Adams et al. (1988) reported unexpectedly high ovulation rates in Galway, but not in Finnish Landrace, ewes after sampling to determine LH. In all our studies, we used animals that had not been subjected to previous experimentation. It is possible that ewes that have been sampled in previous experiments may be less affected by collection of blood samples, because the changes in FSH over time that we observed were not reported by some other workers (Baird $e t$ al., 1981; McNatty et al., 1985).

We conclude that collecting blood samples to measure the frequency of LH pulses in ewes may alter their ovulation rate. The concentration of gonadotrophins measured can also depend on the sampling regimen, and this may explain some of the uncertainty in the relationships between LH, FSH and ovulation rate reported by ourselves and others. Although good experimental designs include controls, they rarely include controls for sampling protocols; the responses to a treatment could therefore still be misinterpreted if the 'control' animals provide abnormal data. For studies of gonadotrophin secretion and ovulation rate, ewes should be habituated to sampling procedures well ahead of the study period, and appropriate (unsampled) controls should be included in the experimental design.

The authors thank the National Hormone and Pituitary Program of the National Institute of Diabetes, Digestive and Kidney Disease for supplying the reagents for $\mathrm{FSH}$, and the 13 people who assisted with collection of the blood samples. The work was supported by The Australian Wool Corporation.

\section{References}

Adams TE, Quirk JF, Hanrahan JP, Adams BM and Watson JG (1988) Gonadotrophin secretion during the periovulatory period in Galway and Finnish Landrace ewes and Finnish Landrace ewes selected for high ovulation rate Joumal of Reproduction and Fertility 83 575-584

Atkinson S and Adams NR (1988) Adrenal glands alter the concentration of oestradiol-17 $\beta$ and its receptor in the uterus of ovariectomized ewes Journal of Endocrinology 118 375-380

Atkinson S, Adams NR and Martin GB (1989) LH, FSH and ovulation rate in ewes treated with exogenous oestradiol Journal of Reproduction and Fertility $86383-390$

Baird DT, Swanston IA and McNeilly AS (1981) Relationships between LH, FSH and prolactin concentrations and the secretion of androgens and oestrogens by the preovulatory follicle in the ewe Biology of Reproduction 24 1013-1025

Braden AWH and Moule GR (1964) Effects of stress on ovarian morphology and oestrous cycles in ewes Australian Joumal of Agricultural Research 15 937-940

Caraty A, Locatelli A, Grino M and Oliver C (1988) Hemorrhage-induced secretion of corticotropin-releasing factor (CRF) does not decrease luteinizing hormone-releasing hormone (LH-RH) release into hypophyseal portal blood circulation of castrated rams Proceeding of the 11th International Congress of Animal Reproduction and AI 216

Doney JM, Gunn RG, Smith WF and Carr WR (1976) Effects of pre-mating environmental strss, $A C T H$, cortisone acetate or metyrapone on oestrus and ovulation in sheep Journal of Agricultural Science 87 127-132

Hall JB, Schillo KK, Hileman SM and Boling JA (1992) Does tyrosine act as a nutritional signal mediating the effects of increased feed intake on luteinizing hormone patterns in growth-restricted lambs? Biology of Reproduction 46 573-579

Li PS and Wagner WC (1983) In vivo and in vitro studies on the effect of adrenocorticotrophic hormone or cortisol on the pituitary response to gonadotropin releasing hormone Biology of Reproduction 29 25-37

McNatty KP, Hudson N, Gibb M, Ball K, Henderson KM, Heath DA, Lun S and Kieboom LE (1985) FSH influences follicle viability, oestradiol biosynthesis and ovulation rate in Romney ewes Journal of Reproduction and Fertility $\mathbf{7 5}$ 121-131

Martin GB, Oldham CM and Lindsay DR (1980) Increased plasma LH levels in seasonally anovular merino ewes following the introduction of rams Animal Reproduction Science 3 125-132

Martin GB, Oldham CM and Lindsay DR (1981) Effect of stress due to laparoscopy on plasma cortisol levels, the preovulatory surge of $\mathrm{LH}$, and ovulation in the ewe Theriogenology 16 39-47 
Martin GB, Taylor PL and McNeilly AS (1987) Effect of small doses of bovine follicular fluid on the tonic secretion of gonadotrophins in the ewe Journal of Endocrinology 114 73-79

Martin GB, Tjondronegoro S and Adams NR (1989) Effect of changes in nutritional status on LH secretion in rams Proceedings of the Australian Society for Reproductive Biology 216

Merriam GR and Wachter KW (1982) Algorithms for the study of episodic hormone secretion American Joumal of Physiology 243 E310-E318

Moberg GP, Watson JG, Stoebel DP and Cook R (1981) Effect of cortisol and dexamethasone on the oestrogen-induced release of luteinizing hormone in the anoestrous ewe Journal of Endocrinology 90 221-227

Parr RA, Davis IF and Tilbrook AJ (1989) Effect of shearing on oestrus and ovulation in sheep Journal of Agricultural Science 113 411-412

Pearce GP, Paterson AM and Hughes PE (1988) Effect of short-term elevations in plasma cortisol concentration on LH secretion in prepubertal gilts journal of Reproduction and Fertility 83 413-418

Phillips DJ and Clarke IJ (1990) Effects of the synthetic glucocorticoid dexamethasone on reproductive function in the ewe Journal of Endocrinology $126 \quad 289-295$

Phillips DJ, Fry RC, Clarke IJ, Egan AR and Cahill LP (1987) Effect of glucocorticoids on the preovulatory LH surge and ovulation rate in the ewe Proceedings of the Australian Society for Reproductive Biology 19142 (Abstract)

Przekop F, Wolinska-Witort E, Mateusiak K., Sadowski B and Domanski E (1984) The effect of prolonged stress on the oestrous cycles and prolactin secretion in sheep Animal Reproduction Science 7 333-342
Przekop F, Polkowska J and Mateusiak K (1988) The effect of prolonged stress on the hypothalamic luteinizing hormone-releasing hormone (LHRH) in the anoestrous ewe Experimental and Clinical Endocrinology 91 334-340

Rasmussen DD and Malven PV (1983) Effects of confinement stress on episodic secretion of LH in ovariectomized sheep Neuroendocrinology 36 392-396

Rawlings NC and Cook SJ (1991) The effects of acclimation to confinement on gonadotrophin and cortisol secretion during the estrous cycle of the ewe Canadian Journal of Animal Science 71 327-332

Rivier C and Rivest S (1991) Effect of stress on the activity of the hypothalamicpituitary-gonadal axis: peripheral and central mechanisms Biology of Reproduction 45 523-532

Sawyer GJ, Lindsay DR and Martin GB (1979) The influence of radiant heat on reproduction in the Merino ewe. III. Duration of oestrus, cyclical oestrous activity, plasma progesterone and LH levels, and fertility of ewes exposed to high temperatures before mating Australian Journal of Agricultural Research 30 1151-1162

Smith JF, Parr JZ and Konlechner J (1992) Confirmation of the 'Adams Effect': rapid blood sampling increases ovulation rate in ewes Proceedings of the Australian Society of Reproductive Biology 2421 (Abstract)

Snedecor GW and Cochrane WG (1967) Statistical Methods (6th Edn). Iowa State University Press, Ames, lowa

Wallace JM and McNeilly AS (1985) Increase in ovulation rate after treatment of ewes with bovine follicular fluid in the luteal phase of the oestrous cycle Joumal of Reproduction and Fertility 73 505-515 